\title{
Transformations of Swedish Labour Market Institutions. Effects on Employees' Turnover Cognitions
}

\author{
Tomas Berglund \\ University of Gothenburg, Sweden \\ Tomas.Berglund@sociology.gu.se
}

\begin{abstract}
The article studies how changes in 2007 in the Swedish unemployment insurance (UI) bave influenced employees' turnover cognitions. It is argued that the combination of a strict employment protection legislation (EPL) and a generous UI in 2006 made employees more inclined to risky transitions. The post-2007 combination of a strict EPL and an ungenerous UI reinforces non-mobility intentions. Analyses of two surveys show a smaller proportion of employees with turnover cognitions in 2010 than in 2006.
\end{abstract}

Keywords: institutional complementarity, labour market institutions, turnover cognitions.

Resumen: El artículo estudia cómo los cambios de 2007 en el subsidio de desempleo sueco ba influenciado en las turnover cognitions (la percepción de los empleados en relación a la movilidad laboral). Se argumenta que la combinación de una legislación estricta que protege el empleo y un generoso subsidio de desempleo en 2006 bizo que los empleados se tomaran más riesgos a la hora de cambiar de empresa. Tras la reforma de 2007 que combinó una protección estricta del empleo con un subsidio de desempleo poco generoso se reforzó la falta de movilidad de los empleados. Los resulados de las encuestas muestran una menor proporción de empleados con turnover cognitions en 2010 que en 2006. 
Tomas Berglund

Palabras clave: complementariedad institucional, instituciones del mercado de trabajo, [turnover cognitions]. 


\section{Introduction}

Sweden has long been renowned for its mix of labour market policies (LMPs), specifically its relatively generous unemployment insurance and extensive use of active labour market measures (Esping-Andersen, 1990; Amable, 2003; Gallie, 2007). In this regard, Swedish employees have enjoyed a high level of security when faced with unemployment. The unemployment insurance (UI) decreases income reduction in the case of unemployment and active measures facilitate the return to employment. Furthermore, Sweden has relatively strict employment protection legislation (EPL), especially for regular employees, which results in high levels of job security.

However, since the 2006 election of the right-wing/centre government (reelected in 2010), Swedish LMPs have undergone radical changes. The UI has become much less generous and covers fewer employees and active measures have been reduced. In combination with other measures, this can be described as a change from a 'high road' to a 'low road' policy in the search for full employment (Bengtsson and Berglund, 2012). On the other hand, the government has been careful not to touch the EPL, arguing that it does not affect the employment rate, which is a key concern. In general, the government wants to keep the Swedish industrial relations model intact (that is, to protect the central importance of collective bargaining).

However, rapid changes in the institutional framework of labour markets can be risky, as theories of 'Institutional Complementarities' have shown (Hall and Soskice, 2001; Amable, 2003; Höpner, 2005; Aoki, 2007; Hall and Gingerich, 2009). These theories assert that the institutional influence on actors can be reinforced by the combination of institutions. This also implies that if the parts of an institutional system are changed, positive complementarities can be lost and negative side effects can occur.

The present article argues that the altered institutional setting in Sweden has affected employees' turnover cognitions (that is, their preferences regarding job-to-job mobility). The Swedish employment protection legislation makes it possible to 'invest' in job protection through tenure. Therefore, the EPL may reduce employees' willingness to change jobs. However, this tendency can be counteracted by a generous unemployment insurance, which compensates for some of the security lost when making transitions between jobs (that is, the risk of becoming unemployed because of a failed transition). One possible consequence of the altered unemployment insurance is that employees become less inclined to make risky transitions and instead try to retain their present job. This hypothesis is tested using two surveys. The first survey was conducted 
before the institutional changes had taken place and the second after the major changes to the unemployment insurance.

The article is structured as follows. It starts by discussing the significance of the EPL and the UI for job mobility. Then the EPL and the UI in Sweden are introduced and the changes that have taken place in these areas are discussed. The next section discusses institutional theories with a focus on institutional complementarities and presents some hypotheses about changes in employees' turnover cognitions as a consequence of institutional changes in Sweden. Then the data are presented, the analytical strategy described and the results outlined. The paper ends with a discussion of the findings and possible upcoming institutional changes regarding the EPL and the UI if low mobility figures are recognized as a political problem.

\section{Turnover cognitions and the significance of employment protection legislation and unemployment insurance}

This article focuses on employees' turnover cognitions: that is, their thoughts about changing employer (Sager, Griffeth and Hom, 1998). Within the organisational psychological literature, this willingness has also been interpreted as 'withdrawal cognitions' (Tett and Meyer, 1993). The most central antecedents for these cognitions are job satisfaction and organisational commitment, but job insecurity has also been shown to be related to turnover cognitions (Berglund, 2007). Furthermore, research has established significant relationships between turnover cognitions and actual quits (Griffeth et alii, 2000; Hom and Kinicki, 2001).

The empirical connection to actual mobility is an argument for the potential importance of turnover cognitions. An overview of the significance of labour market mobility is offered in the OECD's Employment Outlook 2010 (p. 173ff). From a macro perspective, mobility has been shown to be related to productivity growth, in that a fluid labour market facilitates the growth of productive sectors of the economy. However, OECD warns of excessive mobility, which can hamper the accumulation of firm-specific human capital, such as on-the-job training. From the perspective of individual workers, changing jobs may also have some positive consequences. Job-to-job mobility may serve as a way to find a suitable match between individual job preferences and an actual job. Furthermore, voluntary job mobility has been found to correlate with wage gains. 
The purpose of the present analysis is to go beyond the immediate organisational environment and focus on the influence that the institutional context of the EPL and the UI has on turnover cognitions. Research on the EPL has mostly concentrated on the expected behaviour of the employer. In this vein, the strictness of the legislation is believed to affect employers' dismissals and hiring decisions (Skedinger, 2008; OECD, 2010). In the first case, the legislation usually includes rules of notice and priority orders, which restrict employers' opportunities to decide who to fire and when. This may make employers more careful when deciding who to hire. As a consequence of these two mechanisms, stricter EPL can slow mobility rates (especially involuntary mobility). However, the legislation may also affect the voluntary mobility intentions of employees. The rules regarding notice and priority usually build upon seniority or tenure, which makes it possible for employees to invest in protection. Consequently, if a regular employee has invested in protection through tenure, this may make that employee more hesitant to change jobs and lose protection (Furåker and Berglund, 2009; OECD, 2010).

The UI can also influence employees' mobility cognitions. The UI is generally believed to affect the search efforts and reservation wages of unemployed people (Layard, Nickell och Jackman 1991; OECD, 2010). However, the UI can also have more general effects. The UI is a kind of collective risk sharing, which reduces the negative economic impact of unemployment (Schmid, 2008). This, in turn, can make employees more prepared for risky job transitions and more willing to change jobs (Boone, 2004; Sjöberg, 2008).

Empirically, there is some support for these hypotheses on the effects that the EPL and the UI have on turnover cognitions. In an analysis of 1997 data from 18 countries, Souza-Posa and Henneberger (2004) found a significant negative relationship between the strictness of EPL and turnover intentions. In a multilevel analysis of 14 EU countries, Sjöberg (2008) also found a negative relationship between EPL and mobility intentions. Furthermore, a positive relationship was found between the generosity of the UI and mobility intentions.

\section{Employment protection legislation and unemployment insurance in Sweden}

This section describes the Swedish EPL and UI in greater detail. The Swedish Employment Protection Act (Lagen om Anställningsskydd, LAS) dates back to 1974, and has three cornerstones: contracts of employment (duration), objective 
grounds for dismissal, and order of priority in connection with termination of employment (Bylund and Viklund, 2006; Furåker, 2006; Nordic Council of Ministers, $2010 \div 235-38)$. In the normal case, employment contracts are openended and fixed-term contracts are regarded as an exception to the rule. Since then the rules regarding fixed-term contracts have been liberalised. The last change took place in 2007 and abolished a rule allowing a maximum of five temporary contracts per employee. Employees are now allowed an unlimited number.

Another key component of the Employment Protection Act is that notice of termination, which must always be given in writing, must also be based on objective grounds. Shortage of work is generally considered a legitimate cause for dismissal. Furthermore, employers are obliged to give notice in advance of redundancy and/or dismissal. The order of priority stipulates that employees with longer times of employment are entitled to longer periods of notice (Bylund and Viklund, 2006; Furåker and Berglund, 2009). The minimum period is one month for employees with less than two years of employment and increases gradually to a maximum of six months for employees with more than 10 years of employment. Workers who have been laid off have a prioritised right to reemployment at their previous workplace.

A third component of the law is the order of priority for collective dismissals. In accordance with the 'last in, first out' principle, employees who have been in employment longest have priority over other employees in cases of redundancy. In 2000-2001, the Swedish Parliament made another amendment to the law, stipulating that an employer with a maximum of 10 employees is allowed to exempt from this priority order a maximum of two employees who the employer considers to be of particular importance to the company.

It is important to emphasize the fact that the EPL in Sweden is semi-optional: that is, it can be revised both upwards and downwards by collective agreements (Bylund and Viklund, 2006). The rules of objective grounds for dismissal in the Employment Protection Act are not negotiable, whereas the rules regarding contracts of employment (duration) and order of priority in connection with layoffs are open for negotiation. In a study by the Confederation of Swedish Enterprises (Svenskt Näringsliv) — the main employers organization-, it was found that 36 percent of Swedish companies that had made redundancies had made exceptions to the priority rules after negotiations with the unions (Rudeberg and Ingelskog, 2011: 124).

Figure 1 shows OECD's indices on employment protection legislation for 2003 and 2008. The overall indices suggest that Swedish legislation was liberalised between these two years. However, closer examination of the figures 
reveals that the change is due to liberalisation in the use of temporary employees. Looking at the rules for regular employees and collective dismissals, there have been no changes since 2003. This means that the rules of 'first in, last out' and time of notice are intact.

Figure 1. Employment protection legislation 2003 and 2008. OECD's indices. Version 2.

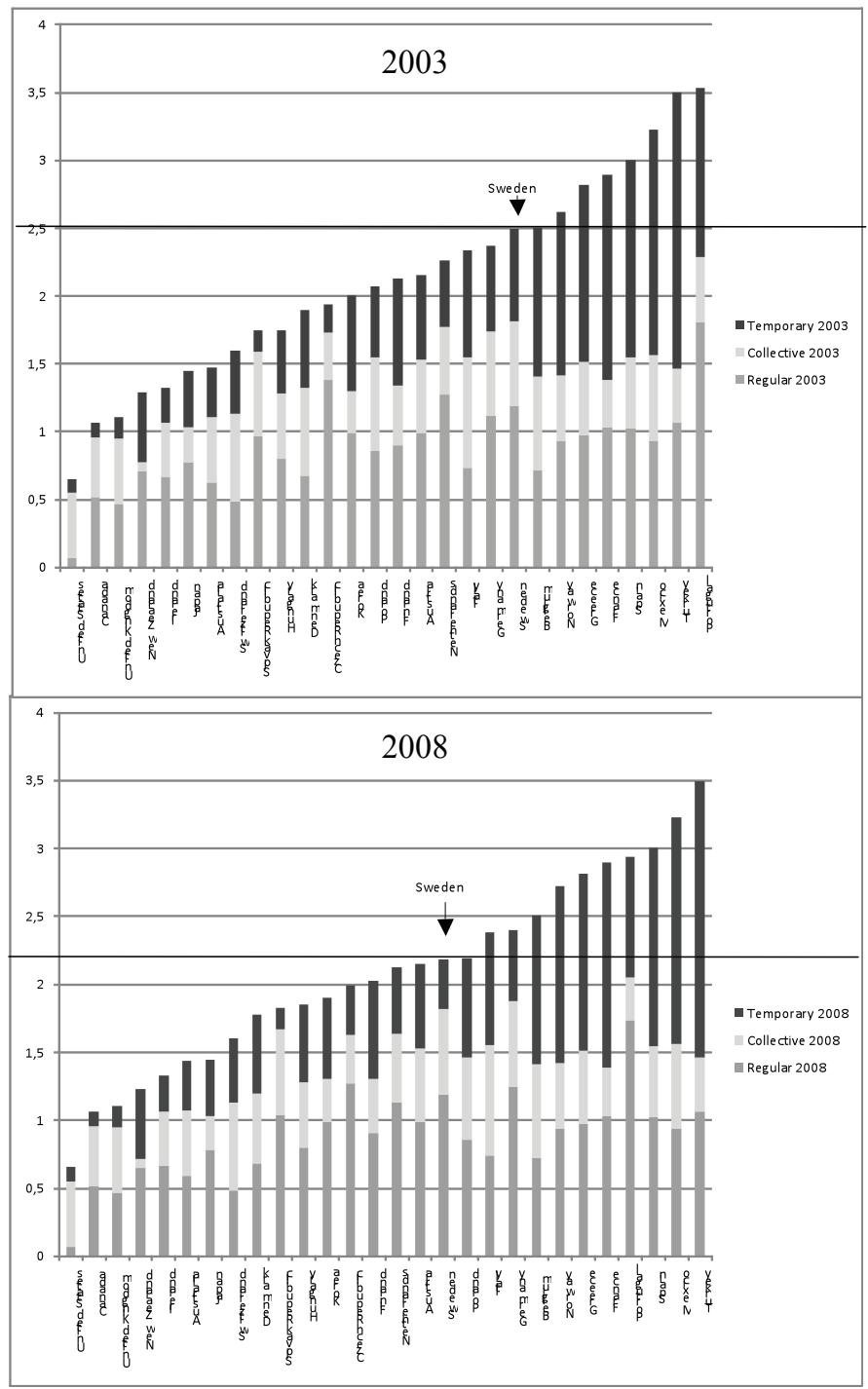


Modern unemployment insurance was introduced in Sweden 1974, the same year as LAS (see Bengtsson \& Berglund, 2012). Since then, however, the UI has been changed several times - mostly in the direction of a less generous UI. The generosity of the insurance can be assessed by looking at the rules of qualification, the duration of benefits and the level of compensation. However, these rules may also be significant for the coverage of the insurance, (that is, if people believe it is worth being a member).

When the modern UI was established, the rules of qualification included a membership and a work requirement (SO, 2008). The membership requirement involved paying a fee for at least 12 months and the work requirement required a working period of at least 75 days in five months (four months from 1989) over a 12 -month period. In the 1990s, the work requirement became stricter, and it was sharpened even further in 2007 by the right-wing/centre coalition government requiring at least 80 hours per month within six of the last 12 months. In the same year, the government also changed the insurance membership fees. The increase was quite dramatic for employed members: from a mean of 99 SEK a month (range 84-120 SEK) in 2006 to a mean of 344 SEK (range 240-415) in 2007 (SO, 2007). The unemployment insurance funds are connected to unions that organize members in different industries (the so-called Ghent system). The purpose of the increase was to change the unemployment insurance into a more 'normal' insurance, in which the fees mirrored the risk of being unemployed in different industries.

The possible duration of the unemployment benefit has not changed a great deal since 1974. The benefit usually applies for 300 days, after which a new work requirement must be fulfilled. Until 2001, however, some of the active labour market programmes qualified as a new work requirement. This was then abolished, together with the entitlement of older workers to have a longer duration (450 days for people aged 55 and over; 57 since 1998). However, it became possible to have the benefit extended for an additional 300 days without fulfilling an extra work requirement. In 2007, this option was removed and the maximum was set at 300 days (except for unemployed people with a child under 18 years, who were entitled to 450 days). The insurance also involved a waiting period before the benefit was paid. Initially, this period was six days; the waiting period was then removed in 1989 but reintroduced in 1993 at five days. In 2008, this was increased to seven days.

The payment levels have decreased steadily since the introduction of the insurance. Prior to 1993, the insurance covered 90 percent of the prior wage (91.7 percent until 1987). Then the compensation level decreased to 80 percent. 
The level of compensation remained stable (except for the year 1996 with a 75 percent payment level) until 2007, when the right-wing/centre coalition government changed the rules again. For the first 200 days, the compensation is 80 percent, and 70 percent thereafter until day 300. If the unemployed person is re-qualified to start a new period, the compensation will be 65 percent. Apart from the compensation level, the unemployment insurance also has a maximum amount; a so-called 'ceiling'. This number has not increased since 2002, despite increases in income. Between 1998 and 2006, approximately 40-50 percent of former full-timers were compensated for up to 80 percent of their wages. In 2010, only 12 percent received 80 percent of their former wages (SO 2010).

However, the development of an unemployment insurance that does not fully compensate its members has created an incentive for unions to bargain for collective supplementary compensations and offer group insurances through the membership fee (Sjögren Lindquist and Wadensjö 2011). Many employees in the Swedish labour market therefore have supplementary insurances for salaries above the ceiling. It is not allowed, however, to have insurances that compensate for more than the maximum level in the public insurance and most supplementary insurances do not pay for the whole 300 day period. Furthermore, complementary insurances are less widespread among blue-collar than among white-collar union members.

Figure 2. Net replacement rates of initial phase of unemployment for two family types with average wage.

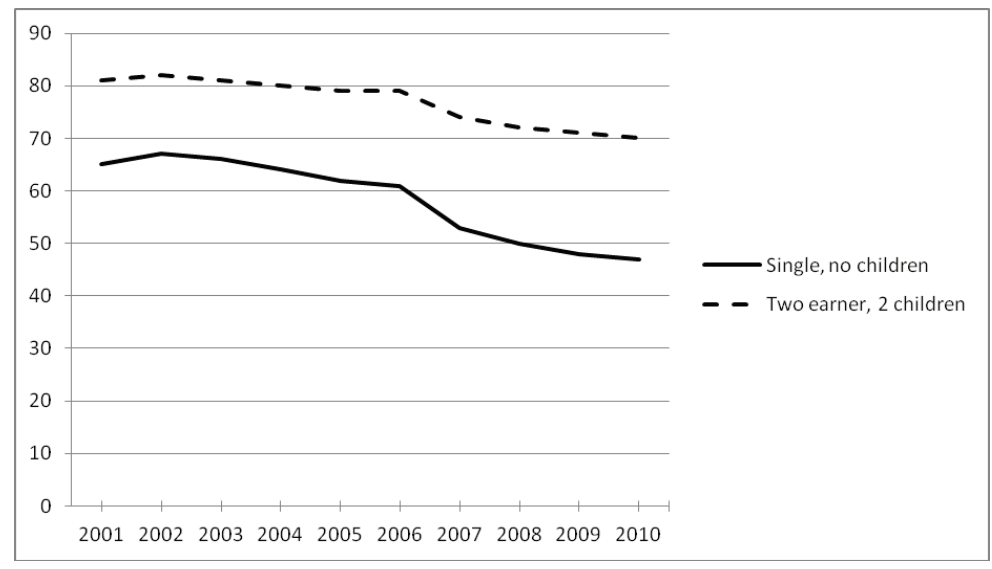

Source: OECD, Tax-Benefit Models, www.oecd.org/els/social/workincentives 23-05-2012. 
A final factor to take into account is the proportion of the labour force covered by the UI (IAF and own calculations). In 1990, the UI had 3,556,000 members, which represented approximately 78 percent of the labour force. During the economic recession in the early 1990s, the number of members increased by about 250,000 and then stabilized. In 2006, there were 3,779,000 members, or 82 percent of the labour force. Within one year, however, approximately 390,000 members had left the insurance, which then covered 73 percent of the workforce. The decline continued until 2009. Mostly the youngest and the oldest members withdrew from the insurance, as did low-income groups (Kjellberg, 2010).

Figure 2 presents OECD figures on the replacement rate to provide a further indication of how the generosity of the UI has changed. The figure indicates the average income before an unemployment spell that is replaced by the unemployment benefit in the initial phase of unemployment. For a two-earner family, the example applies for one spouse losing their job and the other continuing to work full time with earnings equal to 67 percent of the average income. However, the drops in generosity since 2007 are significant for both family types. In fact, in 2010 Sweden was ranked $24^{\text {th }}$ for single earner families and $26^{\text {th }}$ for a two earner family out of 32 OECD countries comparing replacement rates. The Swedish ranking in 2006 was $10^{\text {th }}$ and $15^{\text {th }}$ out of 31 OECD countries.

This overview of the two main institutions under discussion, the EPL and the UI, shows quite dramatic changes in the UI but much more continuity in the EPL. Between 2006 and 2010, the UI became much less generous, implementing stricter work requirements and longer waiting periods, strengthening the demands for search activity, lowering the compensation rate, not increasing the level of the 'ceiling' (despite income increases), and imposing higher membership fees. One possible consequence of these changes is increased income insecurity in the case of unemployment. There have been some changes in the EPL, which concern temporary employees but not regular employees. Among the latter category, no great changes in job insecurity related to the EPL are therefore to be expected. However, there is a risk of a general increase in job insecurity if the use of temporaries becomes widespread in the labour market as a consequence of the 2007 liberalization, although no such tendencies have yet been seen (in 2006, the share of temporary employment was 17 percent; in 2010 it was 15 percent).

\section{Theories of institutional complementarities}

The change in the Swedish institutional system is an interesting case from the perspective of institutional theories. In particular, theories of so-called 
institutional complementarities may be of importance to understand the possible effects and side effects of the comprehensive changes that have taken place.

Before proceeding, it is important to define the concept of institution. Theoretically, it is common to differentiate between three «New Institutionalisms» (Hall and Taylor, 1996). These traditions involve great similarities in the definitions of institutions, although the scope of the presumed significance and influence on actors varies. The most restricted understanding is found in rationalchoice or economic institutionalism. For example, Douglas North (1991: 97) defined institutions as human devices that constrain political, economic and social interaction. Institutions are 'the rules of the game', making human interaction more predictable and lowering transaction costs. However, human preferences and values are understood to be exogenous of the institutional context (although there are exceptions to this view, for example, Aoki (2007)). A more inspiring view of institutions is found in the so-called sociological institutionalism. Here, constraints are not only related to informal and formal rules. Instead, actors' entire understanding of an action situation is affected by the symbols, cognitive schemata, or more general frames of meaning that are made available by the institutional (and cultural) structures. In this way, actors' values and preferences become endogenous from the institutional context. A third perspective is known as historical institutionalism. This involves both 'calculus' approaches, which stress how institutions structure strategic interactions, and 'cultural' approaches, which empasize that institutions are part of the culture that, in a pervasive way, influences actors' identities and preferences.

Other differences between the three institutionalisms are related to the evolution of institutions (Hall and Taylor, 1996). In the rational-choice or economist vision, institutions have evolved as solutions or equilibriums of playtheoretical dilemmas. Therefore, institutions can be regarded as having a rational foundation, although sub-optimal solutions are frequent. The sociological view, on the other hand, is that the institutional setting is more contingent in relation to the interactions that it constrains. Other processes of cultural traditions, social acceptance and political legitimacy are involved, which make suboptimal solutions' to interactions the rule rather than the exception (March and Olsen, 1989). The historical institutional perspective underlines power and conflict in the creation of institutional orders and the role of institutions in the distribution of power.

However, institutional orders have a tendency to create 'path dependency': that is, the institutional setting carries the historical development in a distinct direction. In the discussions of institutional paths and regimes, institutional 
complementarities' has emerged as an important concept. It refers to the combined influence that different institutions have on actors' behaviour (Campbell, 2011). Hall and Soskice $(2001: 17)$ asserted that institutional complementarities exist ‘...if the presence (or efficiency) of one [institution] increases the returns from (or efficiency of) the other'. In other words, the outcomes affected by an institution are reinforced if another complementary institution is present (see also Hall $\&$ Gingerich, 2009). Aoki (2007) described institutional linkages and institutional complementarities. In the first case, institutions from different domains may reinforce actors' action plans and strategic interactions as they benefit from adjusting their actions to institutions in combination rather than in isolation. Institutional complementarities are linkages between institutions where the presence of a certain combination of institutions is more beneficial for the actors than another combination.

In a review of the theories of institutional complementarities, Höpner (2005) points out three implications (see also Amable 2009). Firstly, it may be misleading to focus on a single institution when trying to understand their effects. Secondly, complementarities may restrain institutional change, but sudden changes can have unintended effects. Thirdly, there may be constraints connected to implementing institutional innovations from outside an institutional system. Therefore, institutional paths can be understood as an effect of institutions that are complementary to each other, creating incentives that reinforce certain actions and interactions. It may be difficult to break with the path because of suboptimal outcomes (in the short run) and the occurrence of unintended side effects.

\section{A theoretical framework}

This article uses the following definition of institutions by Hall and Soskice (2001: 9) as a guideline: ‘... we define institutions as a set of rules, formal or informal, that actors generally follow, whether for normative, cognitive, or material reasons ...' However, the distinction made by Jürgen Habermas (1995: 17-22) regarding how actors understand action-situations makes it reasonable not to circumscribe the definition of the action-situation only to material interests, and normative and cognitive components. Instead, material interests should be understood from the more general viewpoint of preferences or values. Institutions, therefore, are formal or informal rules that make certain action-outcomes more probable than others because the institutions influence and constrain the cognitions, values and norms that are reasonable in the action situation. Cognitions are actors' beliefs about what exists (facts) and are related (for example, causal relations) in the 
situation: that is, they are the fundaments for action-plans. Values have to do with what is worthwhile or preferred in the situation: that is, they are evaluated action-goals. Norms are actors' judgements about which types of actions are socially acceptable in the situation and which ones are not (that is, actions that deserve sanctions).

\section{Table 1. A schema of perceptions connected to labour market institutions}

\begin{tabular}{|l|l|l|}
\hline & \multicolumn{1}{|c|}{ EPL } & \multicolumn{1}{c|}{ UI } \\
\hline $\begin{array}{l}\text { Cognitions } \\
\text { (facts, action plans, strategy) }\end{array}$ & $\begin{array}{l}\text { Assessment of job } \\
\text { security }\end{array}$ & $\begin{array}{l}\text { Assessment of income } \\
\text { security }\end{array}$ \\
\hline $\begin{array}{l}\text { Values (evaluated goals or } \\
\text { preferences) }\end{array}$ & $\begin{array}{l}\text { The perceived value of job } \\
\text { security }\end{array}$ & $\begin{array}{l}\text { The perceived value of } \\
\text { income protection }\end{array}$ \\
\hline $\begin{array}{l}\text { Norms (appropriate actions and } \\
\text { legitimizations) }\end{array}$ & $\begin{array}{l}\text { The social } \\
\text { appropriateness of } \\
\text { dismissals/mobility }\end{array}$ & $\begin{array}{l}\text { The social appropriateness of } \\
\text { living on the UI }\end{array}$ \\
\hline
\end{tabular}

Table 1 shows a schematic picture of possible perceptions connected to the institutions that the article focused on. To be useful in the first place, the schema must be delimited to a certain actor; in the present case, the perspective of employees. It is important to underline that the theoretical perspective advocated here does not assume that the particular institutional setting described accounts for all the variations in actors' perceptions; there are many other important factors. For example, with regard to employees' assessment of job security, factors such as the business cycle and type of employment contract are both important (De Witte, 2005).

However, some variation in perceptions is, ceteris paribus, believed to be influenced by the institution in question. Furthermore, the cognitions, values and norms connected with an institution are expected to be coherent to some degree, at least when an institution is stable and on an aggregate level. One reason for this is a general psychological tendency to avoid cognitive dissonance (Festinger, 1957; Schmidt, 2010). Therefore, the possible action repertoire may tend to converge around strategies, goals and norms that can be achieved and upheld. However, if instability occurs, the coherence in perceptions may dissolve.

In line with theories of institutional complementarities, institutions should not be viewed in isolation when attempting to understand their influence on actors. Instead, combinations of institutions are of great significance. However, the concept of 'complementarity' is not used in a value-neutral sense but tends to imply a positive (economic) outcome of some kind. In this regard, it can be appropriate to ask 'complementary for what and for whom?' (cf. Hall, 2005). 
As the present article focuses on employees' turnover cognitions, it is fair to ask whether voluntary labour market mobility is good or bad. In general, some degree of labour market dynamics is believed to be positive for structural transformation in the economy, and also at an individual level for the possibility of suitable matches between subjective preferences and available jobs ( $\mathrm{cf}$. OECD, 2010). However, overly high turnover rates may create instability on a company level (loss of competencies, high costs for recruitment).

Another question is related to the mechanisms involved with creating complementarities. In most cases, the mechanisms are associated with reinforced incentives for certain (positive) actions by the institutions in combination (Amable, 2003: 54ff). However, Crouch (2010: 118ff) argues that complementarities can also arise through compensational mechanisms. In this regard, the incentives and self-interest reinforced by some institutions may not establish sustainable institutional systems; in some cases, they may even be selfdestructive (see Campbell's 2011 analysis of the 2008 financial collapse in the US). In these cases, institutions that counterbalance such effects may be regarded as complementary.

However, the perspective of 'compensational institutions' is not particularly value-neutral and may imply functionalism. In order to overcome these obstacles, this paper will describe the relations between combinations of institutions as reinforcing or counteracting ('non-related' is also a possible empirical finding). Following the above discussion, institutions are believed to influence actors' action plans through structuring the cognitions, values and norms that are found to be reasonable in action situations. The actor must weigh up the combined institutional inputs and reach a decision on how to act. In this sense, the different institutional inputs can reinforce some action plans and counteract or downplay others, which may affect aggregate outcomes. If one outcome is preferred, the institutional setting may be described as complementary, even though different institutions produce reasonable action plans that are counteracting in combination. However, counteracting institutions may still indicate a sub-optimal institutional setting: that is, if reinforcing institutions were in place, the outcome would have been even better. On the other hand, a combination of reinforcing institutions may produce non-preferred outcomes. Such an institutional setting would perform better if counteracting institutions were put in place. 


\section{Swedish institutional reform and hypothesised outcomes on turnover cognitions}

How might the rapid changes in the Swedish UI in combination with the more stable EPL influence employees' turnover cognitions? Are any combined effects expected that would either reinforce or counteract the willingness for job change? The theoretical framework above asserts that the institutions may affect the cognitions, values and norms that are reasonable in the situation and that these combinations may reinforce or counteract certain action plans.

\section{Table 2. Possible influence of EPL and UI in 2006 and 2010 on employees' turnover cognitions}

\begin{tabular}{|c|c|c|c|c|}
\hline & \multicolumn{2}{|c|}{2006} & \multicolumn{2}{|c|}{2010} \\
\hline & $\begin{array}{l}\text { EPL } \\
\text { Strict }\end{array}$ & $\begin{array}{c}\text { UI } \\
\text { Generous }\end{array}$ & $\begin{array}{l}\text { EPL } \\
\text { Strict }\end{array}$ & $\begin{array}{c}\text { UI } \\
\text { Less generous }\end{array}$ \\
\hline $\begin{array}{l}\text { Cognitions } \\
\text { (assessments) }\end{array}$ & $\begin{array}{l}\text { High job security } \\
\text { (for regular) } \\
\text { Investment in } \\
\text { EPL is possible }\end{array}$ & $\begin{array}{l}\text { High income } \\
\text { security } \\
\text { in case of } \\
\text { unemployment }\end{array}$ & $\begin{array}{l}\text { High job } \\
\text { security (for } \\
\text { regular) } \\
\text { Investment in } \\
\text { EPL is possible } \\
\end{array}$ & $\begin{array}{l}\text { Low income } \\
\text { security in case of } \\
\text { unemployment }\end{array}$ \\
\hline $\begin{array}{l}\text { Values (goals or } \\
\text { preferences) }\end{array}$ & $\begin{array}{l}\text { Job security is } \\
\text { important }\end{array}$ & $\begin{array}{l}\text { Affordable to } \\
\text { pay UI }\end{array}$ & $\begin{array}{l}\text { Job security is } \\
\text { important }\end{array}$ & $\begin{array}{l}\text { Less affordable to } \\
\text { pay UI }\end{array}$ \\
\hline $\begin{array}{l}\text { Norms } \\
\text { (appropriate } \\
\text { actions) }\end{array}$ & $\begin{array}{l}\text { Firms should } \\
\text { behave in } \\
\text { accordance with } \\
\text { the spirit of the } \\
\text { law } \\
\text { (In normal } \\
\text { cases, employees } \\
\text { should be loyal to } \\
\text { employers) } \\
\end{array}$ & $\begin{array}{l}\text { It is appropriate } \\
\text { to receive } \\
\text { unemployment } \\
\text { benefit }\end{array}$ & $\begin{array}{l}\text { Firms should } \\
\text { behave in } \\
\text { accordance with } \\
\text { the spirit of the } \\
\text { law } \\
\text { (In normal } \\
\text { cases, employees } \\
\text { should be loyal } \\
\text { to employers) } \\
\end{array}$ & $\begin{array}{l}\text { It is less } \\
\text { appropriate } \\
\text { to receive } \\
\text { unemployment } \\
\text { benefit }\end{array}$ \\
\hline & $\Downarrow$ & $\Downarrow$ & $\Downarrow$ & $\Downarrow$ \\
\hline $\begin{array}{l}\text { Institutional } \\
\text { reasonable action } \\
\text { plans concerning } \\
\text { job change }\end{array}$ & $\begin{array}{l}\text { Investments in } \\
\text { EPL } \\
\text { Internal mobility }\end{array}$ & $\begin{array}{l}\text { External } \\
\text { mobility at bigh } \\
\text { risk }\end{array}$ & $\begin{array}{l}\text { Investments in } \\
\text { EPL } \\
\text { Internal mobility }\end{array}$ & $\begin{array}{l}\text { External mobility } \\
\text { at low risk }\end{array}$ \\
\hline $\begin{array}{l}\text { Reinforcing or } \\
\text { counteracting } \\
\text { action plans } \\
\end{array}$ & \multicolumn{2}{|c|}{$\begin{array}{l}\text { Low incentives for mobility by EPL } \\
\text { are counteracted by the generous UB }\end{array}$} & \multicolumn{2}{|c|}{$\begin{array}{l}\text { Low incentives for mobility by EPL } \\
\text { are reinforced by the less generous } \\
\text { UB }\end{array}$} \\
\hline $\begin{array}{l}\text { Probable } \\
\text { outcome on } \\
\text { aggregate level }\end{array}$ & \multicolumn{4}{|c|}{$\begin{array}{l}\text { Willingness to change employer is, ceteris paribus, lower in } 2010 \text { than in } \\
2006\end{array}$} \\
\hline
\end{tabular}


Table 2 provides an overview of the reasonable cognitions, values and norms in relation to the institutions in question, in both 2006 and 2010. It also shows the influence of the institutions on reasonable action plans concerning voluntary job mobility and whether the institutions reinforce or counteract certain outcomes. Finally, the table shows the hypothesised outcome of the change.

The cognitive aspect of institutions is related to actors' assessments of the situation. In terms of the EPL, it is believed to affect employees' perceptions of job security. As shown above, Swedish legislation is characterized by the opportunity to 'invest' in protection. Generally speaking, the longer an employee stays in a job, the better the job protection. The employment protection legislation did not change greatly between 2006 and 2010. Consequently, employees' cognitions concerning job security may not have changed for this reason.

Furthermore, job security is highly evaluated by employees in Sweden. In a survey in 2005 by the International Social Survey Programme (ISSP) over 90 percent of respondents evaluated job security as an important or very important quality in a job (Berglund, 2012: 54). Likewise, in a survey from 2010 (discussed in greater detail below) that asked the same question, more than 90 percent of respondents regard job security to be important or very important. This value, however, seems to be almost universal in 'wage earner societies' : in a comparison of 27 countries, only two showed figures below 90 percent (Berglund, 2009).

The third aspect of the EPL is whether it is governed by specific norms of behaviours: that is, internalised opinions about what is appropriate behaviour. Firstly, the EPL is a law that, in principle, dictates the behaviour of an employer. The most important informal norms that accompany the law may relate to employees' expectations that employers should behave in accordance with the spirit of the law. For example, there have been some discussions in Sweden concerning whether it is okay to dismiss an employee and then replace him or her with a temporary work agency worker. However, there is no systematic research on these norms in Sweden that can be used here. Furthermore, normative expectations that consider actors other than oneself are not constraining in the same way. Are there any normative expectations connected to the EPL that may constrain the behaviour of employees? One possibility would be that some kind of normative reciprocity develops; that employers' obligations to follow the EPL have a normative correspondence, in that employees should (in normal circumstances) be loyal to their employer.

The UI is believed to influence employees' assessments of income security in case of unemployment. Because of changes to insurance rules, income security is believed to have dropped between 2006 and 2010. In terms of how the insurance 
is evaluated, the loss of members indicates that fewer employees saw the insurance as affordable in 2010 than in 2006. There are also signs that the public discourse about the unemployment insurance has changed since 2006. The right-wing/ centre government has argued strongly that it is the 'work strategy' that is in force and that benefits are only to be used as a last resort and for a very short time period (Bengtsson and Berglund, 2012).

Bringing these factors together, it is reasonable to presume that the employment protection legislation in 2006 and 2010 provides few incentives for voluntary mobility. The construction of the law makes it possible to invest in job security through tenure, and job security is a value that most Swedes regard as important in a job. However, it is less clear whether there are also informal norms in work in the Swedish context that regard loyalty rather than individual mobility as the correct behaviour for employees. The unemployment insurance, on the other hand, has gone through major changes that may affect its significance for transitions and job changes. In 2006, the UI was rather generous and most employees felt it was affordable to pay the fees. Furthermore, the public discourse did not to the same degree problematize the use of unemployment benefits in the case of unemployment. In this way, the insurance provided support for the risky behaviour of changing a job. If a new job turned out to be less secure, the insurance compensated somewhat for a failed transition. In 2010, however, the situation changed dramatically. The UI now gives less protection in the case of unemployment and many employees have left the UI, feeling that it is not affordable. Moreover, public discourse is less indulgent regarding the use of benefits - the so-called work strategy has been propagated (Bengtsson and Berglund, 2012).

Looking at the EPL and the UI in combination, the low incentives for mobility in the EPL in 2006 are counteracted by the relatively generous UI. In 2010, however, the low incentives by the EPL were instead reinforced by the less generous UI. This leads to the expectation that turnover cognitions are, ceteris paribus, lower in 2010 than 2006.

\section{Data and method}

The data used in this paper is based on two postal surveys; one conducted in autumn 2006 and the other in autumn 2010. Both samples used the ordinary labour force survey (LFS) as a sample frame, which has two advantages. Firstly, the sample can be aimed at specific groups in the labour market; the present study targeted employees aged 16 to 64 . Secondly, the variables included in the ordinary labour 
force survey can be used, which provides detailed information about the labour market situation of the respondents, in addition to the questionnaire. The response rates for the surveys were 52 percent in 2006 (1851 responses) and 54 percent in 2010 (2023 responses). In the analyses the two data sets have been merged.

The central dependent variable for the analyses is an indicator of turnover cognitions. The 2010 study asked employees the following question: 'Do you presently want to change employer/workplace?' The possible answers were 'Yes', 'Maybe' or 'No'. However, the 2006 study used three questions to study mobility cognitions: (1) 'Do you presently want to change both employer and workplace?' (2) 'Do you presently want to change employer but not workplace?' (3) 'Do you presently want to change workplace but not employer?' The same answering alternatives were used, except for the last question, which had an additional alternative: 'There is only one workplace'.

To create comparable measures for 2006 and 2010, only the first and third questions in the 2006 study were used. An answer of 'yes' to the 2010 question or to the first or the third 2006 questions indicates turnover cognitions. This construction may overestimate the mobility cognitions in 2006 to some degree. The direct question of changing workplace but not employer may make this alternative more salient than using a slash between employer and workplace. However, using only the first alternative in the 2006 study ('both employer and workplace') is too strict.

Two other variables are used as both dependent and independent variables in the analyses. The first is related to the significance of job security for mobility. Both questionnaires asked the following question: 'How do the following factors in your present workplace affect your will to stay or change employer/workplace?' Several aspects of the work situation were then listed, one of which was 'My job security'. The answer options were: 'It contributes strongly/somewhat to my will to stay,' 'It has no significance' or 'It contributes strongly/somewhat to my will to change. Going back to the theoretical reasoning above, the relative value of job security is expected to increase when job mobility is more hazardous because of a less generous UI since 2006. Another factor related to the greater risk involved in external mobility is the relative value of internal mobility, which should have been higher in 2010 than in 2006. The questionnaires also asked if 'My career prospects' contributed to the will to stay or change employer/workplace. In the present context it will work as a proxy for internal mobility intentions.

The strategy for investigating the hypothesis of reduced turnover cognitions between 2006 and 2010 is to make a dummy variable for the year and use it in a multiple regression and control for as many additional factors as possible 
that may affect the willingness to change job. The analyses used several variables as controls (see the Appendix). However, in relation to earlier research and the analytical purpose of the paper, there are also some key variables.

The first variable is 'Year', which consists of 2006 and 2010. In many ways, this variable is a 'black box', as it contains every non-measured aspect of the situation for employees in the two years. One of these factors is the difference in the institutional systems of EPL and UI. Another factor that may be contained in the variable, however, is a general change in the perceptions of job chances and job security due to the job crises that unfolded in Sweden in the autumn of 2008. In 2006, the unemployment level in Sweden was 7.1 (Statistics Sweden database). For 2008 as a whole, the unemployment level dropped to 6.1 percent. In 2009, however, it suddenly increased to 8.4 percent and continued at this level in 2010. A change in the business cycle usually has a de facto effect on job mobility (Furåker and Berglund, 2009) and turnover cognitions (Sousa-Poza and Henneberger, 2004) in a pro-cyclical direction. Therefore, it is of central importance to control for factors that indicate changes in the labour market situation.

Three variables are used for this purpose. The first is a question about the significance of different factors for external job mobility prospects. One of the listed factors was 'the situation in my local labour market', with five alternative answers ranging from 'not at all limiting' to 'greatly limiting'. A second variable is a question about the risk of losing one's job: 'If there were reductions in your workplace, how do you assess the risk of being one of the first to be let go?' The answers had a five-point scale from 'very large' to 'very small'. The third variable is changes in the unemployment rate at the county level (Swedish 'Län') between the year of the survey and the year before. The use of this variable follows the findings of Sousa-Poza and Henneberger (2004), who showed that turnover cognitions are affected by changes in the unemployment rate rather than the absolute level.

Two other variables of central concern are job satisfaction and organisational commitment, both of which have been shown to be central antecedents of turnover cognitions (Tett and Meyer 1993). The indicator of job satisfaction is a five-point scale for how satisfied or dissatisfied the employee is with their job overall (ranging from 'very satisfied' to 'very dissatisfied'). Organisational commitment is measured (on a five-point scale from 'agree' to 'disagree') by a single statement about how proud the employee is of his or her organisation/ workplace. 
The analyses below have used logistic regression to estimate the effects of the independent variables. The first two analyses focus on the factors that affect employees' views on the significance of job security and career possibilities for their will to stay at the employer. These models have a more extensive and exploratory nature, including all controls to find those factors that are important. The models in the analyses of turnover cognitions are more parsimonious and consist of several steps. In the first analysis, the effect of year is shown together with age, education and sector of employment, which are the variables left of the controls with substantial effects on turnover cognitions. The following three models show the separate effects of the variables measuring the labour market situation (Model 2), job satisfaction and organizational commitment (Model 3 ) and job security and career prospects (Model 4). The last model (Model 5) analyses all the variables together.

\section{Results}

The first step focuses on the two questions about the significance of job security and career prospects on the willingness to stay at one's present workplace. The distributions in Table 3 show that job security and career prospects both seemed to be more important in 2010 than in 2006. In particular, a much larger proportion of people consider job security important for their will to stay.

Table 3. Distributions on the question 'How do the following factors in your present workplace affect your will to stay or change employer/workplace?' regarding job security and career prospects in 2006 and 2010. Percent.

\begin{tabular}{|l|c|c|c|c|}
\hline & $\begin{array}{c}\text { Contributes to } \\
\text { my will to stay }\end{array}$ & No significance & $\begin{array}{c}\text { Contributes to my } \\
\text { will to change }\end{array}$ & Total $(n)$ \\
\hline $\begin{array}{l}\text { My job security } \\
2006\end{array}$ & 42.9 & 48.8 & 8.3 & $100(1797)$ \\
2010 & 63.1 & 30.0 & 6.9 & $100(1977)$ \\
\hline My possibilities for a career & 18.3 & 58.6 & 23.1 & $100(1798)$ \\
2006 & 25.7 & 55.1 & 19.2 & $100(1976)$ \\
2010 & & & \\
\hline
\end{tabular}

Do these results hold when controlling for different factors, especially the perceptions of the labour market situation in 2006 and 2010? Table 4 shows the logarithmic odds ratios that job security and, respectively, career prospects contribute to employees' willingness to stay at the workplace. The odds for the opinions were higher in 2010 than 2006, even when many potential factors are 
controlled in the model. It is particularly important to underline the variables indicating the employment situation in the labour market. The conclusion of these analyses is that there are indications that employees were more hesitant in 2010 to risk job security and place greater value on the opportunities to advance inside the organisation than in 2006.

Table 4. Logistic regression coefficients for job security and career prospects to contribute to employees' willingness to stay with their present employer

\begin{tabular}{|c|c|c|}
\hline Variables & Job security & Career possibilities \\
\hline Year $(2006=0 ; 2010=1)$ & $0.948^{* * *}$ & $0.539^{* * *}$ \\
\hline Gender $($ Male $=0 ;$ Female $=1)$ & $0.187^{*}$ & -0.084 \\
\hline Age category $(0=55-64)$ & & \\
\hline $16-24$ & $-0.459+$ & $0.830^{\star \star}$ \\
\hline $25-34$ & $-0.484^{* *}$ & $1.084^{\star * *}$ \\
\hline $35-44$ & $-0.546^{* * *}$ & $0.619^{* * *}$ \\
\hline $45-54$ & $-0.335^{* *}$ & $0.348^{*}$ \\
\hline Civil status $(0=$ Married $)$ & & \\
\hline Cohabitant & -0.007 & -0.084 \\
\hline Single & -0.007 & -0.209 \\
\hline Children living at home $(\mathrm{No}=0 ; \mathrm{Yes}=1)$ & -0.156 & -0.146 \\
\hline Educational level ( $0=$ Tertiary $)$ & & \\
\hline Primary & $0.511^{\star *}$ & $0.453^{*}$ \\
\hline Secondary & $0.418^{* * *}$ & $0.271^{*}$ \\
\hline $\begin{array}{l}\text { Socio-economic category } \\
(0=\text { Higher white collar })\end{array}$ & & \\
\hline Non-skilled worker & -0.095 & $-0.792^{* * *}$ \\
\hline Skilled worker & 0.107 & $-0.383^{*}$ \\
\hline Lower white collar & 0.046 & -0.275 \\
\hline Middle white collar & 0.018 & -0.101 \\
\hline Monthly wage (5000 SEK increments) & -0.051 & $0.156^{* * *}$ \\
\hline Working time $(0=35$ hours and more $)$ & & \\
\hline $1-19$ & $-0.552+$ & -0.606 \\
\hline $20-34$ & $-0.273^{*}$ & -0.145 \\
\hline Contract $($ Permanent $=0 ;$ Temporary $=1)$ & $-1.484^{* * *}$ & 0.291 \\
\hline $\begin{array}{l}\text { Sector of employment } \\
\text { (Private }=0 ; \text { Public }=1)\end{array}$ & 0.136 & -0.060 \\
\hline No of employees $(0=500$ and more $)$ & & \\
\hline $1-10$ & $-0.646^{* * *}$ & -0.184 \\
\hline $11-19$ & $-0.431^{\star *}$ & $-0.388^{*}$ \\
\hline $20-49$ & $-0.441^{\star *}$ & -0.178 \\
\hline $50-99$ & $-0.405^{* *}$ & -0.161 \\
\hline $100-499$ & -0.123 & -0.056 \\
\hline Union member $(\mathrm{Yes}=0 ; \mathrm{No}=1)$ & $-0.449^{* * *}$ & 0.058 \\
\hline
\end{tabular}




\begin{tabular}{|l|c|c|}
\hline \multicolumn{1}{|c|}{ Variables } & Job security & Career possibilities \\
\hline $\begin{array}{l}\text { Local labour market limits possibilities to change to a } \\
\text { similar or better job (five-point scale, more restricting) }\end{array}$ & $0.070^{*}$ & $-0.065+$ \\
\hline $\begin{array}{l}\text { If there were reductions in your workplace, how do you } \\
\text { assess the risk of being one of the first to be let go? } \\
\text { (five-grade scale, less risk) }\end{array}$ & $0.249^{* * *}$ & 0.045 \\
\hline Change in unemployment level (percent) & 0.067 & $-0.177^{*}$ \\
\hline $\begin{array}{l}\text { Job satisfaction } \\
\text { (five-point scale, less satisfied) }\end{array}$ & $-0.221^{\star * *}$ & $-0.517^{* * *}$ \\
\hline $\begin{array}{l}\text { Proud of organisation } \\
\text { (five-point scale, less proud) }\end{array}$ & $-0.137^{* *}$ & $-0.454^{\star * *}$ \\
\hline Constant & 0.105 & -0.480 \\
\hline Nagelkerke $\mathrm{R}^{2}$ & 0.225 & 0.204 \\
\hline $\mathrm{n}$ & 3059 & 3059 \\
\hline
\end{tabular}

Levels of significance: $+: \mathrm{p}<0.10 ;{ }^{*} \mathrm{p}<0.05 ;{ }^{* *}{ }^{*} \mathrm{p}<0.01 ;{ }^{* *}: \mathrm{p}<0.001$

Table 5 presents the distributions concerning the willingness to change employer/workplace and provides a clear indication of decreasing turnover cognitions. As underlined above, it is important to note that the questions used to measure turnover cognitions are not fully compatible. However, using the more restricted definition in 2006, the figures still indicate a higher level of willingness to change jobs (16.9 percent).

Table 5. Desire to change employer/workplace in 2006 and 2010. Percent.

\begin{tabular}{|c|c|c|c|}
\hline Year & Yes & Maybe $/$ No & Total $(n)$ \\
\hline 2006 & 20.7 & 79.3 & $100(1805)$ \\
2010 & 14.7 & 85.3 & $100(1991)$ \\
\hline
\end{tabular}

Table 6. Logistic regression coefficients for employees' turnover cognitions

\begin{tabular}{|l|c|c|c|c|c|}
\hline Variables & Model 1 & Model 2 & Model 3 & Model 4 & Model 5 \\
\hline Year $(2006=0 ; 2010=1)$ & $-0.366^{* * *}$ & & & & $-0.301^{*}$ \\
\hline Age category $(0=55-64)$ & & & & & \\
$16-24$ & $1.658^{* * *}$ & & & & $1.610^{* * *}$ \\
$25-34$ & $1.282^{* * *}$ & & & & $1.283^{* * *}$ \\
$35-44$ & $0.984^{* * *}$ & & & & $1.044^{* *}$ \\
$45-54$ & $0.664^{* * *}$ & & & & $0.688^{* * *}$ \\
\hline Educational level & & & & & \\
$(0=$ Tertiary) & & & & & \\
Primary & -0.071 & & & & $-0.531^{*}$ \\
Secondary & -0.166 & & & & $-0.398^{* *}$ \\
\hline
\end{tabular}




\begin{tabular}{|l|c|c|c|c|c|}
\hline Variables & Model 1 & Model 2 & Model 3 & Model 4 & Model 5 \\
\hline $\begin{array}{l}\text { Sector of employment } \\
\text { (Private=0; Public=1) }\end{array}$ & $-0.179+$ & & & & $-0.249^{*}$ \\
\hline $\begin{array}{l}\text { Local labour market limit } \\
\text { possibilities to change to a } \\
\text { similar or better job (five- } \\
\text { point scale, more restricting) }\end{array}$ & & $0.065+$ & & & 0.039 \\
\hline $\begin{array}{l}\text { If there were reductions in } \\
\text { your workplace, how do you } \\
\text { assess the risk of being one of } \\
\text { the first to be let go? } \\
\text { (five-grade scale, less risk) }\end{array}$ & & $-0.237^{* * *}$ & & & $-0.075+$ \\
\hline $\begin{array}{l}\text { Change in unemployment } \\
\text { level (percent) }\end{array}$ & & $-0.181^{* *}$ & & & -0.126 \\
\hline $\begin{array}{l}\text { Job satisfaction } \\
\text { (five-point scale, less satisfied) }\end{array}$ & & & $1.172^{* * *}$ & & $1.130^{* * *}$ \\
\hline $\begin{array}{l}\text { Proud of organisation } \\
\text { (five-point scale, less proud) }\end{array}$ & & & $0.443^{\star * *}$ & & $0.460^{* * *}$ \\
\hline $\begin{array}{l}\text { Job security } \\
\text { (go/no signif.=0; stay=1) }\end{array}$ & & & & $-0.704^{* * *}$ & $-0.296^{*}$ \\
\hline $\begin{array}{l}\text { Career possibilities } \\
\text { (go/no signif.=0; stay=1) }\end{array}$ & $-2.020^{* * *}$ & $-0.913^{* * *}$ & $-5.381^{* * *}$ & $0.513^{*}$ & $-4.823^{* * *}$ \\
\hline Constant & 0.063 & 0.033 & 0.290 & 0.058 & 0.351 \\
\hline Nagelkerke $\mathrm{R}^{2}$ & & 3194 & & \\
\hline $\mathbf{n}$ & & & & & \\
\hline
\end{tabular}

Levels of significance: + : $\mathrm{p}<0.10 ;^{*}: \mathrm{p}<0.05 ;{ }^{* *}: \mathrm{p}<0.01 ;{ }^{* * *}: \mathrm{p}<0.001$

The analysis in Table 6 is restricted to the most important factors explaining turnover cognitions. In line with other research (Tett and Meyer, 1993), job satisfaction and organisational commitment have strong effects (Model 3). There are significant effects of the labour market situation (Model 2) and the two variables measuring the importance of job security and career prospects to stay at the employer (Model 4). Year is significant in Model 1, along with age (younger people have more turnover cognitions). In Model 5, when all the variables are included, the effect of year is still statistically significant (that is, employees had fewer turnover cognitions in 2010 than in 2006). Therefore, it can be concluded that there is a difference between the years that are unique, and different from changes in other important factors, such as the indicators of the labour market situation included in the model. 


\section{Conclusions}

Sweden's unemployment insurance underwent significant changes in 2007. It became much less generous: stricter work requirements, more waiting days, greater demands of increased search activity, lower compensation rate, no increase in the level of the 'ceiling' despite income increases, and higher membership fees. At the same time, there were only minor changes in the employment protection legislation: the options for using temporary employees were further liberalised.

This paper has investigated how this change in the combination of UI and EPL has influenced the willingness of employees to make job transitions. Institutional theories, particularly theories of institutional complementarities, assert that it is hard to predict the specific outcome of an institutional change because institutions may have interaction effects on actors. If changes take place at one institution without considering complementary institutions, any reinforcing or compensational effects may change or disappear.

The article has argued that the combination of a strict EPL and a generous UI in 2006 was complementary in terms of external mobility intentions. A strict EPL may make employees less prone to external mobility. This can be counteracted to some degree by a generous UI, which is believed to make employees more inclined to risky transitions. The institutional setting was different in 2010, as the strict EPL was combined with a less generous UI. This combination reinforces non-mobility intentions, in the sense that it is better for employees to hold on to what they have, invest in job protection through tenure and try to improve their situation through internal mobility. This combination is not complementary in relation to mobility but to stability (which can be a desirable outcome in the labour market (see Jonsson, 2007)).

The empirical findings support this prediction. In 2010, a larger share of employees than in 2006 supported the notions that job security and career prospects at their workplace contribute to their desire to stay. These results are probably not the result of improvements in these regards at the organisations. A more plausible interpretation is that employees' evaluations of these facets have changed; job security and internal career prospects exert a stronger restraining force on employees, and they are less prepared to risk them (through external mobility, for example). Furthermore, a smaller proportion of employees wanted to change employers in 2010 than in 2006. These findings point toward reduced willingness for external mobility.

What caused the different perceptions in 2006 and 2010? The regression analyses used year as an independent variable. However, this variable can be regarded as a 'black box' that contains all non-measured aspects of the situation. 
The strategy then was to control for as many factors as possible, thereby ruling out alternative explanations for the effect of year and retaining only the significance of the institutional change. Apart from factors that could be related to the composition of the sample (such as the age distribution) and subjective assessment of the risk of being dismissed, the analysis included the situation in the local labour market, as well as changes in the unemployment rate at the county level. These last factors are of particular importance. A major event, in addition to the changes in the UI, is the economic crisis that started to unfold in the autumn of 2008. The inclusion of these variables hopefully catches some of the subjective concern and insecurity that the crisis may have caused.

This analytical strategy does not rule out every alternative explanation for the 'unique' effect of year. Sweden's right-wing/centre government also introduced other institutional changes, such as a tax reform that cut taxes for people in employment but not for people who were not working, including the unemployed. There is also the possibility that the crisis disrupted people's feelings of security on a more fundamental level, which the questionnaire variables did not capture, making them more risk averse. Furthermore, there is also the possibility of interaction effects, such as the combination of the UI reforms and the crisis.

Taking these alternative explanations into consideration, the UI reform must still be regarded as a major change in the institutional setting of the Swedish labour market. Following institutional theory, the reform had a fundamental impact in terms of changing the 'rules of the game'. The focus of the reformers was to increase the incentives for the unemployed to search for and accept jobs. But there was also a second purpose: making the UI more like normal insurance by letting the fees mirror unemployment should hold back unions' wage demands in sectors with high unemployment (see Finanspolitiska rådet, 2011: 238ff). However, this study has shown that the reforms may have had unintended side effects on employees in terms of making them more risk-averse, thereby hindering external mobility in the labour market.

Is this a serious side effect in the Swedish context? Two studies on mobility in the Swedish labour market have revealed low figures. The first of these studied job-to-job mobility between 1972 and 1998 (Furåker and Berglund, 2009). Before the 1990s crisis in Sweden, approximately 10 percent of employees changed employer every year. During the crisis, this number fell to around six or seven percent, but recovered in the last year of the series to eight percent. A later study of job-to-job mobility between 2000 and 2004 revealed an average of 7.9 percent (Nordic Council of Ministers, 2010). This study also found a large difference between four Nordic countries. The average job-to-job mobility was 
15.7 percent in Denmark, 11.1 percent in Finland and 14.0 percent in Norway. In comparison, the Swedish figures are much lower. However, the decreasing external mobility intentions shown in the above analyses are not promising in this regard. As noted above, studies have shown quite strong correlations between turnover cognitions and de facto job quits (Griffeth et alii, 2000; Hom and Kinicki, 2001).

Table 7. Institutional combinations of EPL and UI and expected mobility outcomes

\begin{tabular}{|c|c|c|c|}
\hline & & \multicolumn{2}{|c|}{ Mobility Outcome } \\
\hline $\begin{array}{l}\text { Effect of } \\
\text { institutional }\end{array}$ & Reinforcing & $\begin{array}{l}++ \\
\text { Danish flexicurity: } \\
\text { Liberal EPL / Generous UI }\end{array}$ & $\begin{array}{l} \\
\text { Sweden 2010: } \\
\text { Strict EPL / Ungenerous UI }\end{array}$ \\
\hline $\begin{array}{l}\text { combination of } \\
\text { EPL and UI }\end{array}$ & Counteracting & $\begin{array}{l}+ \\
\text { US: } \\
\text { Liberal EPL / Ungenerous UI }\end{array}$ & $\begin{array}{l}\text { Sweden 2006: } \\
\text { Strict EPL / Generous UI }\end{array}$ \\
\hline
\end{tabular}

Referring back to the more theoretical questions of institutional complementarities, Table 7 provides an overview of the possible effects of combining EPL and UI. As the present analysis has argued, Sweden in 2006 had a combination of counteracting institutions, which gave employees incentives for both mobility and non-mobility. If willingness for mobility among employees is considered to be positive for society (or the economy), the generous UI can be said to have compensated for the strict EPL. From this perspective, the combination can be regarded as complementary in terms of keeping up mobility intentions. In 2010, the situation changed in Sweden; now the institutional combination can be described as reinforcing. However, it is not reinforcing in the presumed positive direction, producing incentives for mobility. Instead, the analysis points towards incentives for non-mobility: that is, the less generous UI reinforces the incentives of non-mobility by the strict EPL. From this point of view, the institutional combination of EPL and UI in 2010 cannot be said to be complementary.

If Swedish politics suddenly defines low mobility figures as a problem and decides that this is caused by the EPL and the UI, which direction are reforms likely to take? The most probable direction is a return to a more generous UI. From a theoretical point of view, there are other alternatives. One could be the Danish flexicurity road, combining a liberal EPL with generous UI, which evidently reinforces mobility (see Jørgensen and Madsen, 2007; Nordic Council of Ministers, 2010; Berglund and Furåker, 2011). However, this direction may 
be less likely because it involves a more fundamental change in the institutional setup that affects both the EPL and the UI. Another option is the American way, which combines a liberal EPL with an ungenerous UI. Mobility figures in the US are also relatively high (e.g., Jolivet et alii, 2006). However, it is important to note that other factors may encourage mobility in the American context, such as large wage dispersion. A Swedish institutional change in this direction would only involve liberalisation of the EPL. However, it would also entail a direct confrontation with the Swedish unions, especially LO, which the government has avoided so far. Since the changes to the UI, the Swedish unions have been weakened and there have been serious discussions about leaving the Ghent system and introducing an obligatory unemployment insurance. This would most certainly be a new blow to the union rate.

\section{References}

Amable, B. (2003). The Diversity of Modern Capitalism, Published by Oxford Scholarship Online: July 2005.

Amable, B. (2009). «Structural reforms in Europe and the (in)coherence of institutions», Oxford Review of Economic Policy, 25 (1): 17-39.

Aокі, M. (2007). «Endogenizing institutions and institutional changes», Journal of Institutional Economics, 3(1): 1-31.

Bengtsson, M. and Berglund, T. (2012). «Labour market policies in transition: From social engineering to stand-by-ability», in Larsson, B.; Letell, M., and THöRn, H. (eds) Transformations of the Swedish Welfare State: From social engineering to governance? Houndmills, Basingstoke: Palgrave Macmillan, 86103.

Berglund, T. (2007). «Flexible Work Situations and Employees' Thoughts of Leaving the Organization», in FurÅker, B.; HÅkansson, K.; Karlsson, J Ch., (red) Flexibility and Stability in Working Life. Houndmills, Basingstoke, Hampshire: Palgrave Macmillan, 48-172.

Berglund, T. (2009). «Attityder till arbete - en internationell utblick», in Rapport frän konferensen Arbete, livsval och ideal. Norrköping: Arbetets museum, 17-29.

Berglund, T. (2012). «Work Orientations in Western Europe and the United States», in Furåker, B.; Håkansson, K.; Karlsson, J Ch., (eds) Commitment to Work and Job Satisfaction: Studies of Work Orientations. New York: Routledge, 47-66. 
Berglund, T. \& FurÅker, B. (2011). «Flexicurity Institutions and Labour Market Mobility. An Intra-Nordic Comparison», The International Journal of Comparative Labour Law and Industrial Relations, 27(2): 111-127.

Boone, J. (2004). «Unemployment Insurance and Workers' Mobility», Journal of Institutional and Theoretical Economics, 160: 275-293.

Bylund, B. and Viklund, L. (2006). Arbetsrätt $i$ praktiken. En handbok. Stockholm, Norstedts förlag.

Campbell, J.L. (2011). «The US financial crisis: lessons for theories of institutional complementarity», Socio-Economic Review, 9: 211-234.

Crouch, C. (2011). "Complementarity», in Morgan, G.; Campbell, J.L.; Crouch, C.; Pedersen, O.K.; Whitley, R. (Eds) The Oxford Handbook of Comparative Institutional Analysis. Oxford: Oxford University Press, 117-37.

De Witte, H. (2005). «Job Insecurity: Review of The International literature on Definitions, Prevalence, Antecedents and Consequences», Journal of Industrial Psychology, 31(4): 1-6.

Esping-Andersen, G. (1990). The three worlds of welfare capitalism. Cambridge: Polity.

FinANSPOLITISKa RÅdet (2011). Svensk finanspolitik. Finanspolitiska rådets rapport 2011. Stockholm.

FurÅker, B. and Berglund, T. (2009). «Changes of Employer, Employment Protection and Labour Market Attachment: An Analysis of Swedish Data from 1972 to 1998», in Blanpain, R. (ed) The Modernization of Labour Law and Industrial Relations in a Comparative Perspective, The Netherlands: Walters Kluwer, 211-231.

FuRÅKER, B. (2006). «Anställningsform och inställning till rörlighet: en analys av data från tre svenska undersökningar», in Rauhut, D. and Falkenhall, B. (eds) Arbetsrätt, rörlighet och tillväxt, Östersund: Institutet för tillväxtpolitiska studier, 63-91.

Gallie, D. (ed) (2007). Employment Regimes and the Quality of Work, Oxford, Oxford University Press.

Griffeth, R. W.; Hom, P.W. and Gaertner, S. (2000). «A Meta-Analysis of Antecedents and Correlates of Employee Turnover: Update, Moderator Tests, and Research Implications for the Next Millennium», Journal of Management, 26(3): 463-488.

Habermas, J. (1995). Diskurs, rätt och demokrati, Göteborg, Daidalos.

Hall, P. (2005). «Institutional complementarity: causes and effects», SocioEconomic Review, 3:373-377. 
Hall, P. A. and D. Soskice (eds) (2001). Varieties of Capitalism: The Institutional Foundations of Comparative Advantage, Oxford: Oxford University Press.

Hall, P.A. and TAylor, C.R. (1996). «Political Science and the Three New Institutionalisms», Political Studies, XLIV: 936-957.

Hall, P. A. and Gingerich, D. W. (2009). "Varieties of Capitalism and Institutional Complementarities in the Political Economy: An Empirical Analysis», British Journal of Political Science, 39: 449-483.

Hom, P.W. and Kinicki, A. J. (2001). «Toward a Greater Understanding of How

Dissatisfaction Drives Employee Turnover», The Academy of Management Journal, 44(5): 975-987.

Höpner, M. (2005). "What connects industrial relations and corporate governance? Explaining institutional complementarity», Socio-Economic Review, 3: 331-358.

IAF (Swedish Unemployment Insurance Board) <www.iaf.se>.

Jolivet, G.; Postel-Vinay, F; Robin,J-M. (2006). "The empirical content of the job search model: Labor mobility and wage distributions in Europe and the US», European Economic Review, 50: 877-907.

Jonsson , D. (2007). «Flexibility, Stability and Related Concepts», in FurÅker, B.; Håkansson, K. and Karlsson, J. Ch. (eds) Flexibility and Stability in Working Life, Houndmills, Basingstoke, Hampshire, Palgrave Macmillan, $30-41$.

Jørgensen, J. and Madsen, P. K. (eds) (2007). Flexicurity and Beyond. Finding a New Agenda for the European Social Model, Copenhagen, DJØF Publishing. Kjellberg, A. (2010). Vilka 'hoppade av' a-kassan eller avstod från att gå med? En studie av a-kassornas medlemsras, Research Reports 2010:3, Lund, Dept. of Sociology, Lund University.

Layard, R.; Nickell, S.; Jackman, R. (1991) Unemployment:Macroeconomic Performance and the Labour Market Oxford, Oxford University Press.

March,J.G. and J.P. Olsen (1989). Rediscovering Institutions. The Organizational Basis of Politics. New York, The Free Press.

Nordic Council of Ministers (2010). Labour Market Mobility in Nordic Welfare States. Nordic Council of Ministers, TemaNord 2010 515 .

North, D. C. (1991). «Institutions», Journal of Economic Perspectives 5(1): 97112.

OECD (2010). Employment Outlook 2010 - Moving Beyond the Job Crises, Paris. Rudeberg, S. and Ingelskog, J. (2011). Faktiska konsekvenser av turordningsreglerna i LAS och avtal - En rapport av Svenskt Näringsliv och LO. Stockholm: Svenskt Näringsliv och LO. 
Sager, J.K.; Griffeth, R.W. and Нom, P.W. (1998). «A Comparison of Structural Models Representing Turnover Cognitions», Journal of Vocational Behavior, 53: 254-273.

Scнмid, G. (2008). Full Employment in Europe. Managing Labour Market Transitions and Risks. Cheltenham, Edward Elgar.

Sснміdт, V.A. (2010). «Taking ideas and discourse seriously: explaining change through discursive institutionalism as the fourth 'new institutionalism», European Political Science Review, 2(1): 1-25.

SjöвERG, O. (2008). «Labour market mobility and workers' skills in a comparative perspective: exploring the role of unemployment insurance benefits», International Journal of Social Welfare, 17(1): 74-83.

Sjögren Lindquist, G. and Wadensjö, E. (2011). Avtalsbestämda ersättningar, andra kompletterande ersättningar och arbetsutbudet. Finansdepartementet: Expertgruppen för studier i offentlig ekonomi, 2011:4.

Skedinger, P. (2008). Effekter av anställningsskydd. Vad säger forskningen? Stockholm, SNS Förlag.

SO (Swedish Federation of Unemployment Insurance Funds) (2008). Historik över Arbetslöshetsförsäkringen från 1885, Stockholm: Arbetslöshetskassornas Samorganisation.

SO (Swedish Federation of Unemployment Insurance Funds) (2010). Bara en av tio beltidare fär 80 procent, Report 2010-04-29, Stockholm: Arbetslöshetskassornas Samorganisation.

SO (Swedish Federation of Unemployment Insurance Funds) (2007). Konsekvensanalys. Avseende förändringar av a-kassornas finansiering och medlemsavgifterna, Report 2007-09-06. Stockholm: Arbetslöshetskassornas Samorganisation.

Sousa-Poza, A. and Henneberger, F. (2004). «Analyzing Job Mobility with Job Turnover Intentions: An International Comparative Study», Journal of Economic Issues, XXXVIII(1): 113-137.

Tett, R.P. and Meyer, J.P. (1993). «Job Satisfaction, Organizational Commitment, Turnover Intention, and Turnover: Path Analyses Based on Meta-Analytic Findings», Personnel Psychology, 46: 259-293. 